\title{
THE INFLUENCE OF SCIENTIFIC APPROACH AND CONTEXTUAL APPROACH ON MATHEMATICS LEARNING OUTCOMES OF CLASS VII STUDENT SMP NEGERI 2 JERUKLEGI
}

\author{
Dessy Dwi Capriatia, Abdul Taram ${ }^{b}$ \\ Program Studi Pendidikan Matematika Universitas Ahmad Dahlan \\ Jalan Ring Road Selatan, Tamanan, Banguntapan, Bantul Yogyakarta \\ adessy.capriati@gmail.com,
}

\begin{abstract}
Learning activity in SMP Negeri 2 Jeruklegi, Cilacap Regency at mathematics still being dominated by teachers and make students passive in class. This condition has made students in trouble and influence the learning outcomes. The purpose of this study is to know differences in mathematics learning outcomes using scientific, contextual and conventional approaches, and compare what is better to student grade VII mathematics learning outcomes in SMP Negeri 2 Jeruklegi in Cilacap Regency in 2015/2016 academic year. The population in this study is student grade VII at SMP Negeri 2 Jeruklegi, Cilacap Regency of even semester in the 2015/2016 academic year, which is split into seven classes and total students are 222. Sample is taken three classes using a random sampling technique, VII C as experiment class of scientific approach, VII E as experiment class of contextual approach, and VIII D as experiment class of conventional approach. Data collected by documentation and test. This study using experimental with perfect random design. The instrument test includes a validity test, reliability test, and the difference test. Data analysis to condition test include normality test with formula Chi-Quadrate, Homogeneity test with Bartlett Test, and hypothesis test using variance analysis and average test after anava. Based on variance analysis with significance level $\alpha=5 \%$, df numerator $\mathrm{v}_{1}=2$ and $\mathrm{df}$ denominator $\mathrm{v}_{2}=92$ show that: there is difference between mathematics learning outcomes of students using scientific approach, contextual and conventional approach those are showed by $\mathrm{F}_{\text {count }}=6,303458>$ $F_{\text {table }}=3,09543$ and based on RNK test, obtained that contextual approach is better than mathematics learning using scientific and conventional approach to students' mathematics learning outcomes.
\end{abstract}

Keywords: Influence, Scientific Approach, Contextual Approach, Mathematics Learning Outcomes.

\section{INTRODUCTION}

Education is a very decisive process for individual development and community development. The national education function described in Law Number 20 of 2003 concerning the National Education System is: National Education functions to develop capabilities and shape the character and civilization of the nation, aiming for the development of potential students being a man of faith and devotion to God Almighty, noble, healthy, knowledgeable, capable, creative, independent, and a democratic and responsible citizen. The success of students in understanding mathematical material is inseparable from the responsibility of the teacher as the material conveyer as well as educators. Students should not only be seen as passive, silent, monotonous objects but must also be seen as active beings, entitled to service and motivation in learning. According to Slameto in Fathurrohman, Muhammad and Sulistyorini (2012: 120), learning outcomes achieved by students can be influenced by two factors, namely internal and external factors. The main causes of learning difficulties are internal factors, including interest, talent, motivation, level of intelligence, while the main causes of learning problems are external factors, among others in the form of erroneous learning strategies, management of learning activities that do not arouse children's learning motivation and highly influential environmental factors on learning outcomes achieved by students.

In a study, the approach is not everything, but according to Muslich, Mansur (2007: 40), Determination of a particular approach in learning is important for two reasons. First, determining the content of the program, learning materials, learning strategies, learning resources, and techniques/forms of assessment must be inspired by the chosen approach. Second, one of the references to determine the overall stages of learning management is the chosen approach. According to Sukardjono in Hamzah, Ali and Muhlisrarni (2014: 48), mathematics is a way or method of thinking and reasoning, a symbolic 
language that can be understood by all cultured nations, art as in music full of symmetry, patterns, and rhythms that can entertain, tools for map makers, architects, space navigators, machine makers, and accountants. Mathematics has abstract objects of thought/symbol language so generally mathematics is still considered difficult by some students. Based on the even semester midterm scores of grade VII students of SMP Negeri 2 Jeruklegi Cilacap District 2015/2016 academic year on mathematics subjects, showed that there were many mathematics learning outcomes of class VII students below the minimum completeness criteria (KKM) which was able to reach 68. This can be seen in Table 1 below:

Table 1. Summary of UTS Semester Even Mathematics grades VII students Jeruklegi SMP Negeri 2 Cilacap District 2015/2016 Academic Year

\begin{tabular}{|c|c|c|c|c|c|c|c|}
\hline & VII A & VII B & VII C & VII D & VII E & VII F & VII G \\
\hline Average & 52,1 & 50,2 & 49 & 50,6 & 49,3 & 55 & 54,2 \\
\hline$\geq 68$ & $12,5 \%$ & $15,6 \%$ & $3,13 \%$ & $6,3 \%$ & $12,9 \%$ & $21,9 \%$ & $9,7 \%$ \\
\hline$<68$ & $87,5 \%$ & $84,4 \%$ & $96,9 \%$ & $93,8 \%$ & $87,2 \%$ & $78,1 \%$ & $90,3 \%$ \\
\hline
\end{tabular}

(Source: SMP N 2 Jeruklegi)

The results of a brief interview between researchers with Ms. Tity Ambarwulan, S.Pd as the mathematics teacher of SMP Negeri 2 Jeruklegi on October 31, 2015, that students in mathematics learning tended to be less active. Only a few students dare to ask if they have difficulties so that they can affect student learning outcomes in school. In this regard, the teacher must choose and use strategies, approaches, methods, and techniques that involve many students to be active, creative in learning, both mentally, physically, and socially so that they can improve students' mathematics learning outcomes and learning outcomes are expected to be more meaningful to students.

According to Hosnan, M (2014: 34), the scientific approach is a learning approach designed so that active students construct concepts, laws or principles through certain stages. The scientific approach is intended to provide students with an understanding of knowing, understanding various materials using an approach scientifically, that information can come from anywhere, anytime, does not depend on the same direction information from the teacher. The steps in learning with a scientific approach are observing, asking (questioning), gathering information (experimenting), associating / processing information/reasoning (association), and communicating (communicating), with this learning approach students are expected to complete a problematically so that it can improve students' mathematics learning outcomes.

Contextual Teaching and Learning (CTL) according to Sanjaya, Vienna (2008: 109) is a learning approach that emphasizes the process of full student involvement to be able to find the material learned and connect it to real-life situations so as to encourage students to be able to apply it in their lives. Center of Occupational Research and Development (CORD) in Nuzli, Muhammad (2012) delivered five strategies for educators in the context of applying contextual learning, which is abbreviated as REACT, namely: relating, experiencing, applying, cooperating (working together), and transferring (the process of transferring knowledge). Through this contextual learning approach, students can connect mathematical material with their daily lives so that it will be easily understood by students and does not make students quickly forget about the material being taught.

Mathematics learning activities in SMP Negeri 2 Jeruklegi, Cilacap District, from observations, researchers still use conventional learning approaches. According to Majid, Abdul (2013: 165), conventional learning is interpreted as learning in a classical context that is already used to being teacher-centered, so that implementation does not pay attention to the overall learning situation. But in reality, students are still less active and seem to still rely on the teacher and the learning activities greatly influence student learning outcomes.

Based on the background of the problem, the problem can be formulated to be examined as follows: 
1. Is there a difference between the scientific approach, the contextual approach and conventional learning towards the mathematics learning outcomes of seventh graders in the Even Semester of SMP Negeri 2 Jeruklegi Cilacap District 2015/2016 Academic Year?

2. Which approach is better than the scientific approach, the contextual approach and conventional learning on the learning outcomes of seventh-grade students in Even Semester of SMP Negeri 2 Jeruklegi Cilacap District 2015/2016 Academic Year?

In connection with the formulation of the problem described, the objectives to be achieved in this study are:

1. To find out whether or not there are differences in mathematics learning outcomes using the scientific approach by using contextual approaches and conventional learning in VII grade students of Even Semester in SMP Negeri 2 Jeruklegi, Cilacap District, 2015/2016 Academic Year.

2. To find out a better approach from the scientific approach, contextual approach and conventional learning on the learning outcomes of VII grade students of Even Semester in SMP Negeri 2 Jeruklegi Cilacap District 2015/2016 Academic Year.

\section{METHODS}

This type of research is experimental research. According to Sugiyono (2015: 72), "experimental research is research conducted to find specific training for others in the conditions developed". This research was conducted intentionally in class or in school to try to create the variables needed in mathematics learning. The design in this study used three classes, namely three experimental classes. In experimental class 1 using scientific questioning, experimental class 2 uses contextual estimation and experimental class 3 uses conventional. In this study, the posttest was conducted equally for the three experimental classes. Table 2 .

Table 2. Research Design Posttest-Only Design

\begin{tabular}{|l|l|l|l|}
\hline & Group & Treatment & Posttest \\
\hline $\mathrm{R}$ & Eks1 & $\mathrm{X}_{1}$ & $\mathrm{O}_{1}$ \\
\hline $\mathrm{R}$ & Eks2 & $\mathrm{X}_{2}$ & $\mathrm{O}_{2}$ \\
\hline $\mathrm{R}$ & Eks3 & $\mathrm{X}_{3}$ & $\mathrm{O}_{3}$ \\
\hline
\end{tabular}

Information :

$\mathrm{R} \quad$ : random

Eks1 : experimental class scientific approach

Eks2 : experimental class contextual approach

Eks3 : conventional experimental class

$\mathrm{X}_{1} \quad$ : treatment using scientific learning approaches

$\mathrm{X}_{2} \quad$ : treatment using a contextual learning approach

$\mathrm{X}_{3} \quad$ : treatment using conventional learning approaches

$\mathrm{O}_{1} \quad$ : posttest using the scientific learning approach

$\mathrm{O}_{2} \quad$ : posttest using the contextual learning approach

$\mathrm{O}_{3} \quad$ : posttest using a conventional learning approach

According to Sugiyono (2015: 80), the population is a region of generalization consisting of objects/subjects that have certain qualities and characteristics set by researchers to study and then draw conclusions. The population in this study were seventh-grade students of SMP Negeri 2 Jeruklegi of the 2015/2016 academic year which consisted of 7 classes namely VII A, VII B, VII C, VII D, VII E, VII F and VII G classes with 222 students. While the research sample was VII C as the experimental class I and VII E as the experimental class II and VII D with 32 students as the experimental class III selected by random sampling.

Data collection techniques used are documentation methods and test methods. The instrument used in this study was a learning outcome test (posttest) given after receiving treatment with a scientific 
approach, a contextual and conventional approach to the subject of Building a Quadrilateral Flat. Before being tested in the experimental class, so that the learning outcome test questions are arranged not to deviate from the material to be taught, then a grid is made, test questions, and review the items of the test results of mathematics learning.

After the test instruments were arranged, then tested on the instrument trial class, namely class VII B. After the test questions were tested, the test items were analyzed by validity test using the product-moment correlation formula, the discriminating power using the discrimination index formula, and the reliability test using the formula Kuder Richardson-20 (KR-20). Analysis prerequisite test used a normality test with the Chi-Square test and homogeneity test with Bartlet test. Hypothesis testing is used as an anava test.

\section{RESULTS AND DISCUSSION}

Based on the research that has been carried out obtained data in the form of initial abilities and student learning outcomes. The value of the initial ability is obtained from the results of Even Semester Middle Examination grades VII C, VII D, and VII E Jeruklegi 2 Junior High School, Cilacap Regency and obtained the value of the initial mathematical abilities as produced in Table 3.

Table 3. Summary of Description of Initial Capability Value Data

\begin{tabular}{|l|c|c|c|}
\hline \multicolumn{1}{|c|}{ Class } & $\begin{array}{c}\text { Eks Class 1 } \\
\text { (VII C) }\end{array}$ & $\begin{array}{c}\text { Eks Class 2 } \\
\text { (VII E) }\end{array}$ & $\begin{array}{c}\text { Eks Class 3 } \\
\text { (VII D) }\end{array}$ \\
\hline $\begin{array}{l}\text { The number of } \\
\text { students }\end{array}$ & 32 & 31 & 32 \\
\hline The highest score & 81 & 94 & 83 \\
\hline Lowest value & 30 & 25 & 25 \\
\hline Average & 49,00 & 49,3 & 50,6 \\
\hline Standard Deviation & 10,4124 & 15,9812 & 14,7098 \\
\hline Variance & 108,418 & 255,398 & 216,378 \\
\hline
\end{tabular}

The normality test is used to determine whether or not the normal distribution of initial capability data for each experimental class. The researcher calculated the normality test 3 times, namely the normality test for the experimental class. The summary results of the initial capability normality test can be seen in Table 4.

Table 4. Summary of Initial Ability Normality Test Results

\begin{tabular}{|c|c|c|}
\hline Class & $\boldsymbol{\chi}_{\text {count }}^{\mathbf{2}}$ & $\boldsymbol{\chi}_{\text {table }}^{\mathbf{2}}$ \\
\hline Experiment 1 & 1,2802 & 7,8147 \\
\hline Experiment 2 & 1,4528 & 7,8147 \\
\hline Experiment 3 & 2,3209 & 9,4877 \\
\hline
\end{tabular}

From the normality test at a significant level of $5 \%$ and the degree of freedom $=3$, it can be seen that $\chi_{\text {count }}^{2}=1,2802$ and $\chi_{\text {table }}^{2}=7,8147$, so that $\chi_{\text {count }}^{2}<\chi_{\text {table }}^{2}$ which means the experimental class 1 has initial ability data that are normally distributed. In the experimental class 2 , a significant level of $5 \%$ and the degree of freedom $=3$ can be seen that $\chi_{\text {stat }}^{2}=1,4528$ dan $\chi_{\text {table }}^{2}=$ 7,8147 , so that $\chi_{\text {count }}^{2}<\chi_{\text {table }}^{2}$ which means the experimental class 2 has initial ability data that are normally distributed. While the normality test at a significant level of $5 \%$ and the degree of freedom $=$ 4 , it can be seen that $\chi_{\text {count }}^{2}=2,3209$ and $\chi_{\text {table }}^{2}=9,4877$, so that $\chi_{\text {count }}^{2}<\chi_{\text {table }}^{2}$ which means the experimental class 3 has initial ability data that are normally distributed.

The homogeneity test on the data is intended to investigate whether the two samples have the same variance or not. The test used to test the similarity of sample variance is the Bartlet test. The summary results of the initial homogeneity test can be seen in Table 5. 
Table 5. Summary of Initial Ability Homogeneity Test Results

\begin{tabular}{|l|l|}
\hline$\chi_{\text {count }}^{2}$ & $\chi_{\text {table }}^{2}$ \\
\hline 5,797487 & 5,991 \\
\hline
\end{tabular}

From the homogeneity test at a significant level of $5 \%$ and the degree of freedom $=2$, it can be seen that $\chi_{\text {count }}^{2}=5,797487$ and $\chi_{\text {table }}^{2}=5,991$, so that $\chi_{\text {count }}^{2}<\chi_{\text {table }}^{2}$ which means that the three classes have the same variance (homogeneous).

The summary of the results of the hypothesis test of the similarity of initial capabilities can be seen in Table 6.

Table 6. Summary of Initial Ability Anava Hypothesis Test Results

\begin{tabular}{|c|c|}
\hline $\boldsymbol{F}_{\text {count }}$ & $\boldsymbol{F}_{\text {table }}$ \\
\hline 0,1245 & 3,10733 \\
\hline
\end{tabular}

From the hypothesis test the similarity at the $5 \%$ significance level, $v_{1}=2$ and $v_{2}=92$ then it can be seen that $F_{\text {count }}=0,1245$ and $F_{\text {tabel }}=3,10733$, so that $F_{\text {count }}<$ $F_{\text {table }}$ which means there is no difference between the initial abilities of the SMP Negeri 2 Jeruklegi students of Cilacap Regency class VII even the academic year 2015/2016.

Descriptions of data on student mathematics learning outcomes after the experiment are presented in Table 7.

Table 7. Summary of Description of Value of Mathematics Learning Outcomes

\begin{tabular}{|l|c|c|c|}
\hline \multicolumn{1}{|c|}{ Variable } & $\begin{array}{c}\text { Class Eks 1 } \\
\text { (VII C) }\end{array}$ & $\begin{array}{c}\text { Class Eks 2 } \\
\text { (VII E) }\end{array}$ & $\begin{array}{c}\text { Class Eks 3 } \\
\text { (VII D) }\end{array}$ \\
\hline $\begin{array}{l}\text { The number of } \\
\text { students }\end{array}$ & 32 & 31 & 32 \\
\hline $\begin{array}{l}\text { The highest } \\
\text { score }\end{array}$ & 92,31 & 92,31 & 92,31 \\
\hline Lowest value & 30,77 & 46,15 & 23,08 \\
\hline Average & 60,76967 & 72,9536 & 58,4141 \\
\hline $\begin{array}{l}\text { Standard } \\
\text { Deviation }\end{array}$ & 14,6167 & 11,7294 & 16,9052 \\
\hline Variance & 213,648 & 137,579 & 285,78 \\
\hline
\end{tabular}

The normality test is used to determine the normal distribution of learning outcomes for each class of the experiment. The researcher calculates the normality test 3 times, namely the normality test for the experimental class and the normality test. The calculation results show that the experimental class meets the normality requirements. The summary test for normality of learning outcomes can be seen in Table 8.

Table 8. Summary of Normality Tests for Learning Outcomes

\begin{tabular}{|c|c|c|}
\hline Class & $\boldsymbol{\chi}_{\text {count }}^{\mathbf{2}}$ & $\boldsymbol{\chi}_{\text {table }}^{\mathbf{2}}$ \\
\hline Experiment 1 & 3,7478 & 5,9915 \\
\hline Experiment 2 & 2,4013 & 7,8147 \\
\hline Experiment 3 & 3,14304 & 5,9915 \\
\hline
\end{tabular}

From the normality test at a significant level of $5 \%$ and the degree of freedom $=2$, it can be seen that $\chi_{\text {count }}^{2}=3,7478$ and $\chi_{\text {table }}^{2}=5,9915$, so that $\chi_{\text {count }}^{2}<\chi_{\text {table }}^{2}$ which means the experimental class 1 has initial ability data that are normally distributed. In the experimental class 2 , a significant level of $5 \%$ and the degree of freedom $=3$ can be seen that $\chi_{\text {count }}^{2}=2,401329$ and $\chi_{\text {table }}^{2}=7,8147$, so that $\chi_{\text {count }}^{2}<\chi_{\text {table }}^{2}$ which means the experimental class 2 has initial ability 
data that are normally distributed. While the normality test at a significant level of 5\% and the degree of freedom $=2$, it can be seen that $\chi_{\text {count }}^{2}=3,14304$ and $\chi_{\text {table }}^{2}=5,9915$, so that $\chi_{\text {count }}^{2}<$ $\chi^{2}{ }_{\text {table }}$ which means the control class has initial capability data that is normally distributed.

The homogeneity test on learning outcomes data is intended to investigate whether the three samples have the same variance or not. The test used to test the similarity of sample variance is the Bartlet test. The summary test for homogeneity of learning outcomes can be seen in Table 9 .

Table 9. Summary of Homogeneity Test of Learning Outcomes

\begin{tabular}{|c|c|}
\hline$\chi_{\text {count }}^{2}$ & $\chi_{\text {table }}^{2}$ \\
\hline 3,971112 & 5,991 \\
\hline
\end{tabular}

From the homogeneity test at a significant level of $5 \%$ and the degree of freedom $=2$, it can be seen that $\chi_{\text {count }}^{2}=3,971112$ and $\chi_{\text {table }}^{2}=5,991$, so that $\chi_{\text {count }}^{2}<\chi_{\text {table }}^{2}$ which means that the three classes have the same variance (homogeneous).

The summary of the results of the first hypothesis test can be seen in Table 10.

Table 10. Summary of Anava Hypothesis Results of Learning Outcomes

\begin{tabular}{|c|c|}
\hline $\boldsymbol{F}_{\text {count }}$ & $\boldsymbol{F}_{\text {table }}$ \\
\hline 6,303458 & 3,10733 \\
\hline
\end{tabular}

From the hypothesis test the similarity at the $5 \%$ significance level, $v_{1}=2$ and $v_{2}=92$ then it can be seen that $F_{\text {count }}=6,303458$ and $F_{\text {table }}=3,10733$, so that $F_{\text {count }}>F_{\text {table }}$ which means there is a difference between the learning outcomes of students who use the scientific approach, the contextual approach and those who use conventional learning in grade VII even semester of SMP Negeri 2 Jeruklegi Cilacap 2015/2016 academic year.

After it is known that there is a difference between the mathematics learning outcomes of students in the experimental class 1 , experiment 2 with the experimental class 3 , then hypothesis testing after anava is performed using the new man range test of delusions can be seen in Table 11.

Table 11. Summary of Test Results for the Range of Newman Keuls Mathematics Learning Outcomes

\begin{tabular}{|c|c|c|c|}
\hline $\begin{array}{c}\text { Average } \\
\text { compared }\end{array}$ & Difference & RST & Information \\
\hline $\bar{y}_{2}-\bar{y}_{1}$ & 12,18 & 9,961 & $\begin{array}{c}\text { Significantly } \\
\text { different }\end{array}$ \\
\hline $\bar{y}_{1}-\bar{y}_{3}$ & 2,36 & 9,961 & $\begin{array}{c}\text { Not } \\
\text { significantly } \\
\text { different }\end{array}$ \\
\hline $\bar{y}_{2}-\bar{y}_{3}$ & 14,54 & 11,77 & $\begin{array}{c}\text { Significantly } \\
\text { different }\end{array}$ \\
\hline
\end{tabular}

From these results, a significantly different difference was analyzed, namely:

a) Comparison between experimental classes in a contextual approach $\left(\bar{y}_{2}\right)$ and experimental class scientific approach $\left(\bar{y}_{1}\right)$ has an average difference of 12.18 greater than RST which is 9.961 . This means that there is a significant difference between the learning outcomes of the contextual approach and the scientific approach, because $\bar{y}_{2}$ is greater than $\bar{y}_{1}$, it can be concluded that the mathematics learning outcomes using the contextual learning approach are better than mathematics learning using the scientific learning approach.

b) The comparison between the experimental class contextual approach $\left(\bar{y}_{2}\right)$ and the conventional experimental class $\left(\bar{y}_{3}\right)$ has an average difference of 14.54 greater than the RST which is 11,773 . This means that there is a significant difference between the learning outcomes of the contextual approach and conventional learning, because $\bar{y}_{2}$ is greater than $\bar{y}_{3}$, it can be concluded that the mathematics learning outcomes using the contextual learning approach are better than mathematics learning using conventional learning. 
From the hypothesis test after ANOVA it can be concluded that the contextual learning approach is better than the scientific and conventional approach to the mathematics learning outcomes of class VII students even semester SMP Negeri 2 Jeruklegi school year 2015/2016.

\section{CONCLUSION}

Based on the results of research and discussion, conclusions can be drawn, namely:

1. There is a difference between the mathematics learning outcomes of students who take learning using a scientific approach, a contextual approach with mathematics learning outcomes of students who take learning using conventional learning VII grade students in the even semester of the Jeruklegi 2 Junior High School Cilacap District 2015/2016 academic year.

2. The contextual learning approach is better than the scientific and conventional approach to the mathematics learning outcomes of seventh-grade students in the semester of Jeruklegi 2 Public Middle School 2015/2016 academic year.

\section{REFERENCES}

Fathurrohman, Muhammad dan Sulistyorini. 2012. Belajar dan Pembelajaran Membantu Meningkatkan Mutu Pembelajaran sesuai Standar Nasional. Yogyakarta: Teras.

Hamzah, Ali dan Muhlisrarni. 2014. Perencanaan dan Strategi Pembelajaran Matematika. Jakarta: PT RajaGrafindo Persada.

Hosnan, M. 2014. Pendekatan Saintifik dan Kontekstual dalam Pembelajaran Abad 21. Bogor: Ghalia Indonesia.

Majid, Abdul. 2013. Strategi Pembelajaran. Bandung: PT Remaja Rosdakarya.

Muslich, Masnur. 2007. KTSP Pembelajaran Berbasis Kompetensi dan Kontekstual. Jakarta: Bumi Aksara.

Nuzli, Muhammad. 2012. Pembelajaran dengan Pendekatan Kontekstual. http://nuzlimuhammad.blogspot.co.id/2012/07/pembelajaran-dengan-pendekatan_6808.html.

Sanjaya, Wina. 2008. Pembelajaran dalam Implementasi Kurikulum Berbasis Kompetensi. Jakarta: Kencana.

Sudjana. 2002. Desain dan Analisis Eksperimen. Bandung:PT.Tarsito.

Sugiyono. 2015. MetodePenelitian Pendidikan Pendekatan Kuantitatif, Kualitatif dan $R \& D$. Bandung:Alfabeta

Undang-Undang Republik Indonesia No.20 Tahun 2003 Bab 1 Pasal 1 Pendidikan Nasional. 